\title{
Impact of training giving to pediatric nurses by interactive workshops against to problems during lactation period ${ }^{1}$
}

\author{
Dilek Menekse ${ }^{2}$ \\ Nursan Cinar $^{3}$ \\ Ozge Eren ${ }^{4}$ \\ Sevin Altinkaynak ${ }^{5}$
}

\begin{abstract}
Aim: The study has been conducted in order to determine the impact of training which giving to peadiatric nurses by interactive workshops against to problems during lactation period.

Methods: This study, which is an experimental type in which pre-test/ post-test measurements were taken, was carried out in a state hospital in Samsun in October 2014. Before the training, the nurses accepted the presentation invitation. Evaluation of participants' knowledge on the subject was performed via a Multiple Choice Questionnaire (MCQ) prepared by the researchers in relation with the literature. The study was conducted by 33 volunteer nurses working in the pediatric departments of a state hospital in the conference hall. MCQ, consisting of 24 questions, was answered by the participants before and after the interactive workshop. Analyses were performed using commercial software (IBM SPSS Statistics 20, SPSS Inc. An IBM Corp., Armonk, NY)

Findings: Nurses $(\mathrm{n}=33)$ who work in pediatric units participated in the study. The average age of nurses who participated to study is $36.30 \pm 6.47(\mathrm{~min}=21 \mathrm{max}=48)$. There was a significant improvement in mean test score after the lecture when compared with pre-lecture score (Mean $=23.66, \mathrm{SD}=0.54$ vs. Mean $=12.24, \mathrm{SD}=4.11, \mathrm{z}=-5.021 \mathrm{p}=0.000$ )

Conclusions: Lecture based interactive workshop on the problems faced during lactation period helps to improve nurses' knowledge. It also helps in overcoming deficiencies in nurses training.
\end{abstract}

Keywords: Breastfeeding safety; lactation period; nurse training and knowledge; interactive workshop

\footnotetext{
1 This study was presented poster at the 2td Word Congress on Controversies in Pediatrics 16-19 April, Budapest, Hungary, 2015.

2 Assist. Prof. Dr., Sakarya University Faculty of Health Sciences, Department of Peadiatric Nursing, Sakarya, Turkey, dkose@sakarya.edu.tr

3 Prof. Dr., Sakarya University Faculty of Health Sciences, Department of Peadiatric Nursing, Sakarya, Turkey, ndede@sakarya.edu.tr

${ }^{4}$ M.Sc., Samsun Çarşamda State Hospital, Samsun, Turkey, eren_osge@windowslive.com

5 Prof. Dr., Sakarya University Faculty of Health Sciences, Department of Peadiatric Nursing, Sakarya, Turkey, saltinkaynak@sakarya.edu.tr
} 
Menekse, D., Cinar, N., Eren, O., \& Altinkaynak, S. (2019). Impact of training giving to peadiatric nurses by interactive workshops against to problems during lactation period. Journal of Human Sciences, 16(3), 690-699. doi:10.14687/jhs.v16i3.5592

\section{Introduction}

Breastfeeding is the best way of feeding infants. Breastfeeding is providing optimal nutrition for healthy growth and development of infats. Mother's milk is the most appropriate food for infants. There is no food that can be a substitute for breastfeeding (Cinar, Sözeri and Altinkaynak 2009). Breast milk is the ideal food for the infant-with numerous nutritional, immunologic, cognitive, and psychological benefits for the mother/infant dyad (Aune, Norat, Romundstad, and Vatten 2014; Binns, Lee, and Low 2016; Cinar and Dede 2013; Kose, Cinar and Altinkaynak 2013). Today, it is clear that breastfeeding has many benefits for both babies and their mothers. World Health Organization and Ministry of Health strongly advocate breastfeeding (WHO, 2018; Sağlık Bakanlığ1, 2018). Health professionals agree that human milk provides the superior and ideal form of nutrition including premature and sick newborns. However, there are rare exceptions when human milk is not recommended (Eren, Çınar and Altınkaynak 2013; CDC 2018). The cases which breast milk should not be given are very limited and short-dated (Eren, Çinar and Alttnkaynak 2013). It is possible that diseases of mother and medicines mother uses cross into infant through breast milk, besides, in some cases infants are unnecessarily destitute of breast milk because of fear based on uncertainty and lack of knowledge (Lawrence 2011). A physician will need to make assessment to determine whether a woman's environmental exposure or her own medical condition warrants her to interrupt or stop breast feeding under certain circumstances (CDC 2018).

For instance; the mothers who suffer from Botulism and toxoplasma (Lawrence 2011) and carry Hepatitis A (Daudi, Shouval, Stein, and Ackerman 2012; Lawrence, 2011) and Hepatitis C (Mass, 2004; Schilllie et al. 2018) can securely breastfeed their babies. In the presence of Hepatitis A, while synchronously inoculating the infant with immune globulin $(\mathrm{Ig})$ and Hepatitis A Virus (HAV), mothers who carry Hepatitis $C$ should take a pause only if they have inflammation in their breast (Lawrence 2011). If the nursing mother has mumps, she continues to breastfeed rather than giving a pause because Ig A in breast milk decreases the symptoms in infant (Cinar and Sahin 2003; Lamounier, Moulin and Xavier 2004; Lawrence 2011). Within these illnesses and cases, giving a pause to breast feeding causes that infants are destitute of protective, nutritious and emotional potentials of breast milk when the infants maximally need the breast milk (Lawrence 2011; Eren, Çınar and Altınkaynak 2013)

In some cases the mother needs to give a short pause to breast feeding. It has big importance for maternal and infant health that the nurse who mentors for breast feeding correctly directs the mother. In the presence of brucellosis mastitis and tuberculosis mastitis, it is suggested that the breast feeding should be temporarily abandoned till the breast recovers and lesion dries. When these two cases are present for mother, stimulation of milk production is procured by milking with pump (Lamounier, Moulin and Xavier 2004; Haratipour, Sohrabi, Zolfaghari, and Enayatfard 2008). In the presence of meningococcus infection, the breast feeding is maintained according to general situation of the mother after the mother and infant start to treatment (Eren, Çinar and Altunkaynak 2013). Mother who is infected with Human Immunodeficiency Virus (HIV) can breastfeed her infant after proper antiretroviral (ARV) treatment is applied (Çınar and Şahin 2003; Yalçın 2011).

Mothers can use computerized tomography or magnetic resonance imaging methods for the purpose of diagnosis and treatment in breast feeding period (Ozturk and Ertem 2014). In this case, mothers might need the guidance of health care professionals for what to do about maintaining or giving a pause to breast feeding. According to performed studies, it is stated that a small percentage of Iodic X-Ray contrast substance passes to breast milk and this contrast substance is absorbed by the bowels of infant (ACR, 2012; Kubik-Huch et al., 2000; Ozturk and Ertem 2014). If the mother 
Menekse, D., Cinar, N., Eren, O., \& Altinkaynak, S. (2019). Impact of training giving to peadiatric nurses by interactive workshops against to problems during lactation period. Journal of Human Sciences, 16(3), 690-699. doi:10.14687/jhs.v16i3.5592

is suspicious or worried about breast feeding; she can give a 24 hours pause to breast feeding infant (ACR 2012; Kubik-Huch et al. 2000; Ozturk and Ertem 2014).

It is known that mothers who are infected with Cytomegalovirus (CMV) and breast milk which contains chemotherapy and tamoxifen after the breast cancer treatment and breast feeding are exactly contraindicated (Arisoy 2011; Helewa, Lévesque, and Provencher 2002). During the Radiotherapy which is required for the treatment, breast feeding and human milk can be paused according to kinds of radiation used and treatment time (Helewa et al. 2002). Knowing the cases which breast milk and breast feeding are definitely contraindicated is important for breast feeding security in lactation period.

\section{Purpose}

This study was performed in order to designate the effect of education with interactive workshop method which was given to pediatric nurses intended for problems faced in lactation period.

\section{Methods}

\subsection{The place and time of study}

The study was conducted in a state hospital in Samsun on October 2014.

\subsection{Population and sample selection}

Some of the participant nurses had to be on duty during the time of study, so a total of $89.1 \%$ $(33 / 37)$ of the intended population could be reached. Volunteering 33 nurses made up the sample group. The incusion criteria were as follows: (a) working as nurse in the pediatric departments of a state hospital in Samsun; (b) having received the consent to participate in this study.

\subsection{Type of study}

The study was pre-post test experimental descriptive type

\subsection{Data collection}

The study was conducted in the conference hall of a state hospital by the participation of 33 voluntary nurses working in pediatric departments. The purpose of the study explained again and questions of participants regarding issue responded. Nurses had accepted an invitation to the presentation prior to the training event. A prelecture MCQ test was completed by nurses at the beginning of the workshop. The MCQ's were derived from topics covered in the presentation. Following the lecture the MCQ test was repeated again. A post lecture MCQ test was completed to assess retention and application of knowledge derived from the interactive lecture. The participants were not informed about whether the test would be repeated after the training.

\subsubsection{Data collection tools}

In the study, data were collected using the "Nurse Information Form" and the Multiple Choice Questionnaire (MCQ). Data collection procedure lasted in approximately 10-15minutes. Lecturebased workshop on the problems faced during lactation period continued about 35- 40 minutes.

\section{Nurse Information Form}

"Nurse information form" which was prepared by the researchers in order to determine sociodemographic information of the nurses (age, educational background, breastfeeding experience, etc.) consists of 6 questions. 
Menekse, D., Cinar, N., Eren, O., \& Altinkaynak, S. (2019). Impact of training giving to peadiatric nurses by interactive workshops against to problems during lactation period. Journal of Human Sciences, 16(3), 690-699. doi:10.14687/jhs.v16i3.5592

\section{Multiple Choice Questionnaire (MCQ)}

Evaluation of nurses' knowledge on the subject was performed via a Multiple Choice Questionnaire (MCQ) prepared by the researchers [an academic pediatric nurse (Prof. Dr.), a pediatrician (Prof. MD), a PhD student in pediatric nurse and a Msc student in pediatric nurse] in relation with the literature. Final form of MCQ is determined in accordance with suggestions of experts and the number of questions is designated as 24 (Appendix A). Each question in the MCQ was considered as 1 point. The maximum score to get from the test was 24 . Nurses attended an interactive lecturebased workshop on problems during lactation period.

\subsection{Limitation of study}

One of the limitations of this study that it did not reach to all nurses who are related with the topic within the region where the study has performed. Number of nurses who work in related services are $37.89 .1 \%(33 / 37)$ of them could join the study. Some of the nurses were on the duty on the day of study performed that is why they could not join the study.

\section{6 .Research ethics}

The study was started after the necessary permissions are taken from the Directorate of Secretariat of Samsun Province The Public Hospitals Union and from the public hospitals that field nurses work for. Before the interview, the purpose and duration of study were explained to the nurses who agreed to participate in the study.

\subsection{Evulation of data}

It has been evaluated by kolmogrov simirnow test whether the data have shown a normal distribution or not. wilcoxon signed ranks test has been used since the data haven't shown a normal distribution. Distribution was found out to be quite symmetrical according to Bixplot, pre-test and post-test results were found to be statistically significant according to Wilcoxon Signed Ranks Test $(\mathrm{z}=-5.021, \mathrm{p}=0.000)$.A $\mathrm{p}$-value $<0.05$ was considered statistically significant. Analyses were performed using commercial software (IBM SPSS Statistics 20, SPSS Inc. An IBM Corp., Armonk, NY)

\section{Results}

Thirty-two womenand one man; in total 33 nurses who work in services related with children joined the study. The average age of nurses who participated to study is $36.30 \pm 6.47$ ( $\mathrm{min}=21$ $\max =48)$. It was notified by nurses that $78.8 \%$ of nurses $(26 / 33)$ have bachelor's degree, $84.8 \%$ have children (28/33), nurses who have children have also the experience of breast feeding (28/ 28), $90.9 \%$ of them (30/33) received a breast-feeding education and $81.8 \%$ of them $(27 / 33)$ have enough knowledge about breast feeding and human milk.

There was a significant improvement in mean test score after the lecture when compared with prelecture score (Post-test min.22 points/max.24 points Mean $=23.66, \mathrm{SD}=0.54$ vs. Pre-test min. 6 points $/$ max.22 points Mean=12.24, $\mathrm{SD}=4.11, \mathrm{z}=-5.021 \mathrm{p}=0.000)($ Table 1).

Table 1. Pre-Workshop and Post-Workshop Test Scores

\begin{tabular}{llll}
\hline MCQ & $\mathbf{n}$ & Mean \pm SD & Test statistics* \\
\cline { 1 - 3 } Pre-workshop test & 33 & $12.24 \pm 4.11$ & $\mathrm{z}=-5.021$ \\
\cline { 1 - 3 } Post-workshop test & $33.66 \pm 0.54$ & $\mathrm{p}=0.000$ \\
\hline
\end{tabular}

*Wilcoxon signed ranks test $\mathrm{p}<0.001$ 
Menekse, D., Cinar, N., Eren, O., \& Altinkaynak, S. (2019). Impact of training giving to peadiatric nurses by interactive workshops against to problems during lactation period. Journal of Human Sciences, 16(3), 690-699. doi:10.14687/jhs.v16i3.5592

\section{Discussion}

Health education which is performed with workshop method state to benefit from workshop education for transferring knowledge to family and to society in order to evaluate effect of given education, to create awareness about information and attitude and redound positive behavior. In literature search we could not encounter with any study which evaluates effect of workshop education method towards problems seen in lactation period. However when the educations given to nurses in different fields with workshop method are examined, it is seen that there are evidences which show education performed with workshop method has positive effects (Altun, Cinar and Barin 2010; Altun and Zencirci 2010; Altun and Zencirci 2011; Altun 2010; Tiryaki and Cinar 2016). In this study, effects of given education about this topic and knowledge level of nurses towards problems seen in lactation period are examined. In this study MCQ which consists of 24 questions is used. It is determined that total score average that participants took from MCQ before the education is $12.24 \pm 4.11(\min =6, \max =22)$. This score showed that nurses do not have enough knowledge. Interactive PowerPoint presentation which consists of answers of questions is performed for participants and final test is executed with same questions. Total score average that participants received after education raised to $23.66 \pm 0.54(\min =22, \max =24)$. When MCQ scores of working group are compared before and after the education; score average of after education was higher than score average before education. Moreover, it is determined that differences between are statistically and significantly meaningful.

\section{Conclusion and Suggestions}

This result has showed that given education and used method positively contributed to nurses for health problems seen in lactation period and knowledge towards these questions. Studies depend on this kind of education and performed with small groups are an effective method in order to complete imperfect knowledge and correct the wrong information. When it is considered that breast milk is the most suitable nourishment for the infant and considered that situations require to cut the breast feeding is very limited, it is clear that nurses shall have enough knowledge regarding with the topic. Method used in study provided nurses to inform about the topic and it is seen that method was an effective tool. In this study, nurses who work as volunteer have formed the sample. However, this topic informs all the health care professionals. It will be very useful to transmit these educations to larger groups within certain periods in order to provide infants more this unique nutrition and to prevent unnecessarily interruptions for breast feeding.

\section{Acknowledgements}

We cordially thank to the nurses who participated in this study.

\section{Declaration of Interest}

Authors declare no conflict of interest.

\section{Funding/Support}

We received no funding from any organization for this research. 
Menekse, D., Cinar, N., Eren, O., \& Altinkaynak, S. (2019). Impact of training giving to peadiatric nurses by interactive workshops against to problems during lactation period. Journal of Human Sciences, 16(3), 690-699. doi:10.14687/jhs.v16i3.5592

\section{References}

Altun, I., Cinar, N.D. \& Barin, Ö.C. (2010). Best practice techniques for administration of injections: Impact of lecture based interactive workshops on training of nurses. Pakistan Journal of Medical Sciences, 26, 152-157.

Altun, I. \& Zencirci, A.D. (2010). Management of fever and hyperthermia: Impact of lecture based interactive workshops on training of nurses. Libyan Journal of Medicine, 5, 5140.

Altun, I. \& Zencirci, A.D. (2011). Knowledge and management of pressure ulcers: Impact of lecturebased interactive workshops on training of nurses. Advances in Skin \&Wound Care: Journal for Prevention and Healing, 24, 262-266.

Altun, I. (2010). The efficacy of workshop on body fluids in health and disease and its impact on nurses training. Pak J Med Sci., 26 (2), 426-429.

American College of Radiology [ACR]. (2016). ACR Committee on Drugs and Contrast Media, Version 10,2. https://geiselmed.dartmouth.edu/radiology/pdf/ACR_manual.pdf

Arısoy, E.S. (2011). Sitomegalovirüs enfeksiyonlar1: Etken ve epidemiyoloji. Journal of Pediatric Infection, 5(1), 208-212.

Aune, D., Norat, T., Romundstad, P. \& Vatten, L.J. (2014). Breastfeeding and the maternal risk of type 2 diabetes: a systematic review and dose-response meta-analysis of cohort studies. Nutr Metab Cardiovasc Dis, 24: 107-115.

Binns, C., Lee, M. \& Low, W.Y. (2016). The long-term public health benefits of breastfeeding. AsiaPacific Journal of Public Health, 28 (1), 7-14.

Bultery, M. \& Kourtis, M.D. The future of breastfeeding in the face of hiv-1 infection: science and policy. A.P. Kourtis and M. Bulterys (eds.), Human Immunodefi ciency Virus type 1 (HIV-1) and Breastfeeding, 301 Advances in Experimental Medicine and Biology 743, Doi 10.1007/978-1-4614-2251-8_22.

Centers for Disease Control and Prevention [CDC]._Breastfeeding: Diseases and Conditions. Erişim 03.03.2015 https://www.cdc.gov/breastfeeding/breastfeeding-specialcircumstances/contraindications-to-breastfeeding.html

Cinar, N.D. \& Sahin, S. (2003). Maternal diseases and breastfeeding. Marmara Medical Journal, 16(4), 292296. https://doi.org/10.7599/hmr.2010.30.1.60

Cinar N, Dede C. (2013). Why breast feeding is the best feeding? Health Scope, 2(1): 63-64.

Cinar, N.D., Sozeri, C.U., \& Altınkaynak, S. (2009). Başarlı nesiller için anne sütü. Sağhcakla Ayllk Sağhlk Dergisi, 12: 20-21.

Daudi, N., Shouval, D., Stein, Z.C. \& Ackerman, Z. (2012). Breastmilk hepatitis A virüs RNA in nursing mothers with acute hepatitis A virüs infection. Breastfeed Medicine, 7: 313-315.

Eren, O., Çınar, N. \& Altınkaynak S. (2013). Laktasyon döneminde görülen hastalıklarda ilaç kullanımında emzirme güvenliği. STED, 22 (4),149-56.

Haratipour, H., Sohrabi, M.B., Zolfaghari, P. \& Enayatfard, M. (2008). Breastfeeding transmission of brucellosis. Iranian Journal of Clinical Infectious Diseases, 3(2),105-107.

Helewa, M., Lévesque, P., \& Provencher, D. (2002). Breast cancer, pregnancy, and breastfeeding. Journal of Obstetrics and Gynaecology Canada, 24(2), 164-180.

Köse, D., Çınar, N. \& Altınkaynak, S.(2013). Yenidoğanın anne ve baba ile bağlanma süreci. STED, 22 (6), 239-245.

Kubik-Huch, R.A., Gottstein-Aalame, N.M., Frenzel, T., Seifert, B., Puchert, E., Wittek, S. \& Debatin, J.F. (2000). Gadopentetate dimeglumine excretion into human breast milk during lactation. Radiology, 216, 555-558.

Lamounier, J.A., Moulin, Z.S. \& Xavier, C.C. (2004). Recommendations for breastfeeding during maternal infections, Jornal de Pediatria, 80 (5), 181-188.

Lawrence RM. (2011). Transmission of infectious diseases through breast milk and breastfeeding. In: Lawrence RA, Lawrence RM, editors. Breastfeeding: a guide for the medical profession. 7th ed. New York: Mosby.

Mast, E.E. (2004). Mother to infant hepatitis $C$ virüs transmission and breastfeeding. Advances in Experimental Medicine and Biology, 554, 211-216. 
Menekse, D., Cinar, N., Eren, O., \& Altinkaynak, S. (2019). Impact of training giving to peadiatric nurses by interactive workshops against to problems during lactation period. Journal of Human Sciences, 16(3), 690-699. doi:10.14687/jhs.v16i3.5592

Ozturk, R. \& Ertem, G. (2014). Emziren annelerde kontrast madde içeren görüntüleme yöntemleri kullanilabilir mi? Hemşirelikete Eğitim ve Arastirma Dergisi, 11(1), 30-33.

Sağllk Bakanlığı [SB]. (2018). Sağllklı nesiller için anne sütü broşürü, Erişim 3 Mart 2018. https://dosyasb.saglik.gov.tr/Eklenti/11801,anne-sutunun-onemipdf.pdf?

Schilllie, S., Vellozzi, C., Reingold, A., Harris, A., Haber, P., Ward, J.W. \& Nelson, N.P. (2018). Prevention of Hepatitis B virus infection in the United States: Recommendations of the advisory committee on immunization practices. MMWR, 67 (RR-1), 1-31.

Tiryaki, Ö. \& Cinar, N. (2016). Management of continuous positive airway pressure in the newborn: Impact of lecture-based interactive workshops on training for neonatal intensive care nurses. Aquichan, 16 (2), 159-168. http://dx.doi.org/10.5294/aqui.2016.16.2.4.

World Health Organization [WHO]. (2018). Breastfeeding. Erişim 28.05.2018 http://www.who.int/topics/breastfeeding/en/

Yalcin, S.S. (2011). HIV pozitif anne bebeğinin beslenmesi, 2010 Dünya Sağlık Örgütü önerileri. Cocuk Sağhğı ve Hastalkklar Dergisi, 54(1), 51-54.

\section{Appendix A}

For each given question select the single best answer from the choices provided (A\&E)

1. Which is the most suitable period for the breast feeding after birth?

a- First half hour

b- First 1 hour

c- First 2 hours

d- First 3 hours

e- First 6 hours

2. Those below are inductions for breast milk concentrator.. Please mark the wrong one.

a- Infant who does not gain weight.

b- Birth weight $<1500 \mathrm{gr}$

c- Lack of expected grow around head

d- Preterm infant

e- Gestation age $<27$ weeks

3. Which of those below is not suitable for breast feeding technique?

a- Mouth of infant is large and open

b- The lower lip turned out

c- Big areola around of mouth

d- Chin of infant touches to breast

e- Cheeks of infant become straight to mother's breast

4. Which of those is wrong to suggest to mother who has straight or collapsed nipples?

a- Massage to nipples during the gestation

b- Nipple devices

c- Applying pump before nutrition

d- Infant should be placed to breast well

e- Nipples should be examined during the third trimester of gestation.

5. Which of those is wrong in case of mastitis?

a- Mother should not breastfeed her infant

b- A hot application should be applied to breast

c- Lactose concentration decreases in breast milk with mastitis.

d- Medical drainage and antibiotics are required in the presence of apse

e- Mother should increase fluid intake 
Menekse, D., Cinar, N., Eren, O., \& Altinkaynak, S. (2019). Impact of training giving to peadiatric nurses by interactive workshops against to problems during lactation period. Journal of Human Sciences, 16(3), 690-699. doi:10.14687/jhs.v16i3.5592

6. Which of those correct in case of hyperactive let-down?

a- Milk production above the consumption capacity of infant

b- Colic is frequently

c- Malabsorption can be seen.

d- Mother should breastfeed her infant after milking some of her milk.

e- Diaper dermatitis is frequent

7. Which of those is wrong in case of hypergalactia?

a- Milk leaks from the breast between feedings

b-The infant consumes milk with poor lactose

c- Infant has frequently and plenty of defecation

d- Weight gain of infant is inadequate

e- Breastfeeding with another breast before having enough discharge from one breast.

8. Which of those is wrong for the breast milk yellowness?

a- Seen in $2 \%$ of infants

b- Emerge at the end of first week

c- Breast milk is abandoned if the indirect bilirubin is $10 \mathrm{mg} / \mathrm{dl}$.

d- Quickly recovers if the breast milk is paused for 3-4 days.

e- Dividing diagnosis should be made for the other yellowness reasons of infant

9. Which of those below is not suggested for the mother who exercises in lactation period? Mark the wrong one.

a- A medium degree exercise can be taken

b- Can breastfeed right after exercise

c- Should take a shower after exercise

d- Should suckle the first milk by milking after exercise

e- Taste of milk changes after the exercise

10. Which of the following is suitable within infant feeding for mother who suffers from Hepatitis B infection during the lactation period?

a- Feeding with breast milk is kept

b- Breast milk should be given after pasteurization

c- Breast milk is contraindicated.

d- Adapted formula should be given

e- Breast milk should be given by milking.

11. Our suggestion for breast milk of mother who suffers from Hepatitis A in lactation period; Mark the correct one.

a- Breast milk is not given

b- Breast milk is kept

c- Breast milk should be given after pasteurization

d- Breast milk is given after freezing

e- Given as formula

12. Which of those is correct for mother who suffers from Hepatitis $\mathrm{C}$ in lactation?

a- Breast milk is not given

b- Breast milk is given unless there is liver failure

c- Breast milk is given if she receives chemotherapy

d- Infant can breastfeed if there is HIV infection

e- If mother receives antiviral treatment, breast milk is not given 
Menekse, D., Cinar, N., Eren, O., \& Altinkaynak, S. (2019). Impact of training giving to peadiatric nurses by interactive workshops against to problems during lactation period. Journal of Human Sciences, 16(3), 690-699. doi:10.14687/jhs.v16i3.5592

13. Which of those below should be done for infant feeding of mother who suffers from measles in lactation period?

a- Breast feeding is kept.

b- Milked human milk should be given

c- Adapted formula should be given

$\mathrm{d}$ - Breast milk is contraindicated

e- Pasteurized breast milk should be given

14. In which of those below, breast milk is not contraindicated?

A Breast cancer in lactation period

b- Heavy malnutrition depending on chronical disease of mother

c- Mother takes a medicine which causes addiction

d- Measles in mother

e- Heavy psychiatric disorder in mother

15. Which of those below is the case that breast milk is certainly contraindicated?

a- Hepatitis C

b- Hepatitis B

c- Lyme disease

d- Receiving chemotherapy for breast cancer

e- Tuberculosis infection

16. If there is tuberculosis infection in mother, which of those below is correct for the suggestion of breast milk?

a- Breast milk is given

b- Breast milk is given by pasteurization

c- Breast milk is given by freezing

$\mathrm{d}$ - Breast milk is not given

e- If basil $(+)$ in phlegm, infant can breastfeed

17. Which of the following is correct for our suggestion to human milk of mother who suffers from active tuberculosis?

a- Breast milk and INH prophylaxis are given to infant

b- Breast milk is not given

c- Breast mill is given by pasteurization

$\mathrm{d}$ - Breast milk is given by freezing

e- If basil (+) in phlegm, infant can breastfeed

18. Which of the following the breast milk is contraindicated?

a- HBV in mother

b- Contact of mother with person who has active tuberculosis

c- HAV in mother

d- HCV in mother

e- CMV IgM(+) in mother

19. In which of the following breast milk is contraindicated?

a- HIV infection in mother

b- Pneumonia in mother

c- HCV in mother

d- CMV IgM(+) in mother

e- HBV in mother 
Menekse, D., Cinar, N., Eren, O., \& Altinkaynak, S. (2019). Impact of training giving to peadiatric nurses by interactive workshops against to problems during lactation period. Journal of Human Sciences, 16(3), 690-699. doi:10.14687/jhs.v16i3.5592

20. Which of the following is a metabolic disease that can be supported with breast milk?

a- Phenylketonuria

b- Galactosemia

c- Hyperlipidemia Type I

d- Abetalipoproteinemi

e- Urea cycle enzyme deficiency

21. Those below are the topics to be paid attention while suggesting medicines to mother in lactation period. Mark the wrong one.

a- If the medicine is definitely required, it shall be taken

b- The most secured medicine shall be selected

c- If this medicine can harm the infant, serum concentration shall be monitored if it is possible

$\mathrm{d}$ - The infant shall be suckled after taking the medicine

e- Mother shall take a medicine before put infant to sleep

22. Which of those medicines can be taken by mother during the lactation period?
a- Cytotoxic agents
b- Cocaine
c- Heroin
d- Radioactive substance
e- Penicillin

23. Which of those can be taken by mother if she breastfeed?
a- Antidepressant
b- Antipsychotic
c- Antipyretic
d- Heroin
e- Cocaine

24. Which of the following is suitable for birth control of mother who is in lactation period?

a- Giving the breast milk is enough

b- Intra uterine device

c- Medicine consists of estrogen+ progsterone

d- Medicine consists of estrogen

e- Medicine consists of progsterone

Answers: 1-a, 2-d, 3-c, 4-a, 5-a, 6-d, 7-b, 8-c, 9-b, 10-a, 11-b, 12-b, 13-b, 14-d, 15-d, 16-a, 17-a, 18-e, 19d, 20-a, 21-d, 22-e, 23-c, 24-b 